\title{
Leuprorelin acetate affects ERK1/2 activity in prostate cancer cells
}

\author{
FORTUNATA IACOPINO, GINA LAMA, CRISTIANA ANGELUCCI and GIGLIOLA SICA
}

\author{
Istituto di Istologia ed Embriologia, Facoltà di Medicina e Chirurgia, \\ Università Cattolica del Sacro Cuore, Largo Francesco Vito 1, 00168 Rome, Italy
}

Received January 31, 2006; Accepted March 28, 2006

\begin{abstract}
The mechanisms by which a GnRH analogue, leuprorelin acetate (LA), antagonizes the mitogenic effect of dihydrotestosterone (DHT) or epidermal growth factor (EGF) in prostate cancer cells is poorly understood. The mitogenactivated protein kinase system has a central role in growth regulation and, for this reason, we investigated the involvement of the extracellular signal-regulated kinase (ERK1/2) pathway in the response of both androgen-sensitive ( $\mathrm{LNCaP}$ ) and -insensitive (PC-3) prostate cancer cells to LA alone or combined with EGF or DHT. The evaluation of ERK activation was performed by using Western blot analysis and immunocytochemistry. EGF specifically induced ERK1/2 activity in both models and this effect was counteracted by an inhibitor of EGF-receptor phosphorylation. The addition of LA produced an appreciable reduction of ERK phosphorylation promoted by EGF in LNCaP cells, while it generally determined an increase in ERK activity in androgen-unresponsive PC-3 cells. The slight ERK activation induced by DHT in LNCaP cells was counteracted by LA and this effect was evident only by immunocytochemistry. Our findings suggest that the antiproliferative effect of LA in prostate cancer cells stimulated by hormones and growth factors may be, at least in part, mediated by the reduction of ERK1/2 activation in LNCaP cells and linked to the unexpected increase of this activity produced by the analogue in PC-3 cells.
\end{abstract}

\section{Introduction}

The hypothalamic decapeptide gonadotropin-releasing hormone $(\mathrm{GnRH})$ is a key regulator of the mammalian reproductive system, triggering the synthesis and release of follicle-stimulating hormone (FSH) and luteinizing hormone (LH) in the pituitary (1).

Correspondence to: Professor Gigliola Sica, Istituto di Istologia ed Embriologia, Facoltà di Medicina e Chirurgia, Università Cattolica del Sacro Cuore, Largo F. Vito 1, 00168 Rome, Italy E-mail: ibiis@rm.unicatt.it

Key words: ERK activity, prostate cancer cell proliferation, epidermal growth factor, dihydrotestosterone, GnRH agonist
In the past, hundreds of agonists and antagonists of GnRH have been developed and various applications in different fields of medicine have been established for these analogues. In particular, they have been investigated for their therapeutic advantages in hormone-related tumors. GnRH agonist administration results in hormone ablation (chemical castration) which can effectively replace surgical castration (2). The slowing-down of neoplastic cell growth is based on the reduction of sex steroid supply (3). In addition, it is widely accepted that GnRH analogues may act directly on tumor cells via specific receptors expressed on cell membrane. Several reports have provided evidence that GnRH analogues negatively control the proliferation of breast, ovarian, endometrial and prostate cancer cells (2). Nevertheless, the mechanisms that underlie this direct action are poorly understood.

In our experience, the $\mathrm{GnRH}$ agonist, leuprorelin acetate (LA), which is ineffective when used alone, counteracts or even suppresses the androgen-induced growth of androgensensitive prostate cancer cells, $\mathrm{LNCaP}$, and reduces the mitogenic effect of epidermal growth factor (EGF) in androgeninsensitive PC-3 cells. Moreover, in both models, LA reduces the expression of the PSA gene, evaluated by reverse transcriptase-polymerase chain reaction, and inhibits the gene expression induced by dihydrotestosterone (DHT) in LNCaP cells and EGF in PC-3 cells $(4,5)$.

More recently, we have shown that LA significantly reduces the DHT-promoted expression of the antiapoptotic gene, bcl-2, evaluated at both the mRNA and protein level, without inducing apoptosis in the LNCaP cells (6).

The extracellular signal-regulated kinase, ERK1/2, belongs to the larger mitogen-activated protein (MAP) kinase family and is generally involved in cell division and differentiation (7). In the pathogenesis and development of prostate cancer, most growth and oncogenic signals have been implicated and lead to tyrosine phosphorylation which, in turn, activates MAP kinase cascade $(8,9)$.

The present study deals with the role played by ERK1/2 in determining the antiproliferative effect of LA observed by our group in prostate cancer cells only in the presence of DHT or EGF. Further experiments were performed regarding the effect of EGF, alone or combined with LA, on both LNCaP and PC-3 cells. ERK1/2 expression has been evaluated by both Western blotting and immunocytochemistry in LNCaP and PC-3 cells exposed to different treatments. 


\section{Materials and methods}

Compounds. Leuprorelin acetate (LA), D-Leu6-(des-Gly10NH2) LHRH ethylamide was kindly donated by Takeda Italia Farmaceutici SpA, Rome, Italy. It was dissolved in saline solution and stored at $4^{\circ} \mathrm{C}$.

$5 \alpha$-dihydrotestosterone (DHT), epidermal growth factor (EGF) and tyrphostin (AG1478) were purchased from Sigma (St. Louis, MO, USA). Stock solutions were made by dissolving DHT and AG1478 in absolute ethanol, and EGF in a $10 \mathrm{mM}$ acetic acid buffer containing $0.1 \%$ BSA and stored at $4^{\circ} \mathrm{C}$.

Antibodies. Anti-phospho-p44/42 MAP kinase, Thr202/ Tyr204 (pERK1/2), anti-phosphorylation state independent p44/42 MAP kinase (ERK1/2), rabbit polyclonal antibodies and the secondary antibody, horseradish peroxidase (HRP)labeled goat anti-rabbit IgG, were from Cell Signalling Technology, Inc. (Newcastle, USA). The secondary biotinylated goat anti-rabbit antibody was from Vector Laboratories (Burlingame, CA, USA).

Cell cultures. The hormone-sensitive $\mathrm{LNCaP}$ cell line was used between passages 33 and 54 and cultured in RPMI-1640 medium (Eurobio, Les Ulis Cedex B, France), supplemented with $10 \%$ (v/v) foetal bovine serum (FBS, ICN Biomedicals, Costa Mesa, CA, USA), 10 mM N-2-hydroxyethylpiperazineN'-2-ethane sulfonic acid (Hepes buffer, Eurobio) and antibiotics.

Hormone-insensitive PC-3 cells were used between passages 76 and 92 and were routinely cultured in Dulbecco's modified Eagle's medium (DMEM, Eurobio), supplemented with 5\% FBS, Hepes buffer and antibiotics.

Both cell lines were sub-cultured weekly. They were maintained in a humidified air: $\mathrm{CO}_{2}$ atmosphere (95\%:5\%) at $37^{\circ} \mathrm{C}$.

Cell proliferation assays. The mitogenic effects of EGF on both $\mathrm{LNCaP}$ and PC-3 cells were investigated. There is no agreement in the literature about the culture conditions used to investigate the proliferative effects of EGF on LNCaP cells (10-12). In the present study, LNCaP cells were seeded into $60-\mathrm{mm}$ plastic Petri dishes at two different densities, i.e. 25,000 and 50,000 cells $/ \mathrm{ml}$ culture medium, and allowed to adhere to the culture plate. After $48 \mathrm{~h}$, cells were fed with fresh medium supplemented with $5 \%$ charcoal-treated FBS (CH-FBS) and EGF (0.1-50 ng/ml of culture medium).

PC-3 cells were plated at a density of 25,000 cells $/ \mathrm{ml}$ of standard culture medium in $60-\mathrm{mm}$ plastic plates. Cells were allowed to adhere and, $24 \mathrm{~h}$ after plating, the seeding medium was replaced with fresh DMEM supplemented with 5\% $\mathrm{CH}$ FBS and the above-mentioned EGF concentrations. The fresh medium containing EGF was renewed 2 days after the first change.

In another series of experiments, both $\mathrm{LNCaP}$ and PC-3 cells were exposed to $10 \mathrm{ng} / \mathrm{ml} \mathrm{EGF}$ in combination with LA at concentrations from $10^{-11}$ to $10^{-5} \mathrm{M}$. Medium containing EGF was changed 2 days after the first medium renewal and LA was added every day. Cell counts were performed with a hemocytometer after 2 and 4 days.
Finally, proliferation experiments were also performed in the same conditions as those used for Western blot analysis. Cells were counted after 2 days of treatment with the different compounds.

Triplicate cultures were set up for each drug concentration and control dishes containing untreated cells were run in parallel with the same amount of vehicle. Cell viability was assessed by Trypan blue exclusion test.

\section{Western blot analysis}

Cell treatment. Cells were seeded and cultured in 100-mm plates to approximately $60 \%$ confluence in the presence of serum-containing medium. They were then cultured in low serum medium ( $0.5 \% \mathrm{CH}-\mathrm{FBS})$ for $48 \mathrm{~h}$ to reduce basal levels of phosphorylated MAP kinases. Prior to treatment with hormones and growth factors, the medium was renewed again to abolish the MAP kinase phosphorylation due to factors secreted by cells. Then, LNCaP cells were treated for 5,10 , 30,60 and $240 \mathrm{~min}$ with various concentrations of LA $\left(10^{-11}\right.$, $\left.10^{-6}, 10^{-5} \mathrm{M}\right)$, DHT $\left(10^{-9}-10^{-7}, 10^{-5} \mathrm{M}\right)$ and EGF $(10 \mathrm{ng} / \mathrm{ml})$ in serum-free medium, while PC-3 were exposed to LA $\left(10^{-11}\right.$ and $\left.10^{-5} \mathrm{M}\right)$ and EGF $(10 \mathrm{ng} / \mathrm{ml})$ for the same time periods. In a series of experiments, cells were treated with LA and EGF simultaneously or they were pre-treated with LA $15 \mathrm{~min}$ prior to the exposure to $10 \mathrm{ng} / \mathrm{ml}$ EGF.

A number of plates from each experiment were treated with $300 \mathrm{nM}$ tyrphostin (AG1478), a selective inhibitor of the tyrosine kinase of the EGF receptor, 30 min prior to treatment with EGF.

Following exposure to different compounds for the various time periods, cells were washed twice with ice-cold phosphate buffered saline (PBS) without $\mathrm{Ca}^{2+}$ and $\mathrm{Mg}^{2+}, \mathrm{pH} 7.6$, collected by mechanical scraping and lysed in lysis buffer [50 mM Tris- $\mathrm{HCl}$ ( $\mathrm{pH} \mathrm{8.0),} 150 \mathrm{mM} \mathrm{NaCl}$, sodium dodecyl sulfate $0.1 \%$ (SDS), $1 \%$ Nonidet P-40, $0.5 \%$ sodium deoxycholate, $100 \mu \mathrm{g} / \mathrm{ml}$ phenylmethylsulfonylfluoride, $1 \mathrm{mM}$ sodium vanadate and $30 \mu \mathrm{g} / \mathrm{ml}$ aprotinin] on ice for $30 \mathrm{~min}$. Cell debris was removed by centrifugation $\left(12,000 \mathrm{x}\right.$ g per $10 \mathrm{~min}$ at $\left.4^{\circ} \mathrm{C}\right)$ and the protein content of the supernatants was determined using a modified version of Lowry's method (13).

Immunoblot of phosphorylated-ERK1 and ERK2 (pERK1 and $p E R K 2)$. Samples (40 $\mu \mathrm{g}$ of proteins) and control protein (nonphosphorylated and fully phosphorylated ERK2) were resolved on denaturing polyacrylamide gels $12 \%$ (SDS/ PAGE) and transferred to polyvinylidene difluoride (PVDF; Immobilon P, Millipore Corp., Bedford, MA, USA) membrane by electroblotting. Membranes were blocked with TBS-T (Tris- $\mathrm{HCl}$ buffer saline with $0.1 \%$ Tween-20) containing $5 \%$ non-fat dry milk for $2 \mathrm{~h}$ and then incubated overnight at $4{ }^{\circ} \mathrm{C}$ with primary antibodies against pERK1/2 (dilution 1:750) in TBS-T containing 5\% non-fat dry milk. After washing for $3 \times 5 \mathrm{~min}$, membranes were probed for $1 \mathrm{~h}$ at room temperature with an HRP-conjugated anti-rabbit antibody (1:2000) in TBS-T containing 5\% non-fat dry milk. Specific proteins were visualised by enhanced chemiluminescence reagents using protocols described by the supplier (Phototope-HRP Western detection kit; Cell Signalling Technology) and visualised on Hyperfilm ECL (Amersham, Buckinghamshire, UK). The signals were quantitated by densitometric scanning 
(ChemiDoc documentation system/QuantityOne quantitation software; Bio-Rad Laboratories, Hercules, CA, USA).

Uniformity of loading was determined by the immunolocalization of total MAP kinase using an anti-total ERK1/2 polyclonal antibody. For this reason, stripping of PDVF membranes was accomplished by placing the membranes in a solution containing $62.5 \mathrm{mM}$ Tris ( $\mathrm{pH} 6.8$ ), $2 \%$ SDS and $100 \mathrm{mM}$ 2-mercaptoethanol, and heating to $50^{\circ} \mathrm{C}$ for $30 \mathrm{~min}$. Then, membranes were washed for $3 \times 10 \mathrm{~min}$ in TBS-T, blocked with TBS-T containing 5\% non-fat dry milk for $2 \mathrm{~h}$ and incubated overnight at $4^{\circ} \mathrm{C}$ for total MAP kinase levels with anti-total ERK1/2 polyclonal antibody diluted 1:2000. Thereafter, the procedure was exactly as detailed for the active-MAP kinase antibody.

Densitometric units of the protein pERK1 and pERK2 were corrected for the densitometric units of total ERK1 and ERK2. The ratio pERK/total ERK from each treated sample was then divided by the value determined under control or EGF conditions to obtain the fold enhancement or reduction of the activated protein.

Immunocytochemistry. In immunocytochemical experiments, LNCaP cells (density: 25,000 cells/ml) and PC-3 cells (density: 13,000 cells $/ \mathrm{ml}$ ) were seeded in standard medium on sterile circular glass coverslips $(\varnothing 18 \mathrm{~mm}$ ) placed on the bottom of tissue culture plates (353043, Multiwell ${ }^{\mathrm{TM}} 12$ well; BectonDickinson and Company, Franklin Lakes, NJ, USA). The procedure for cell culture and treatment was the same as described for the Western blot experiments. However, before treatment, the cells were maintained in serum-free medium for $2 \mathrm{~h}$.

At the end of treatment, the culture medium was removed from the tissue culture plates and cells were washed with PBS. Then they were fixed with $3 \%$ paraformaldehyde in PBS and washed with $50 \mathrm{mM}$ Tris- $\mathrm{HCl}$ (pH 7.4), $150 \mathrm{mM}$ $\mathrm{NaCl}$ solution (TBS) containing $0.1 \%$ Triton X-100 (TBST). Subsequently, non-specific binding was blocked with $5.5 \%$ normal goat serum in TBST for $60 \mathrm{~min}$ at room temperature. Incubation with primary antibody anti-pERK1/2 diluted (1:250) in TBST containing 3\% BSA was performed for $24 \mathrm{~h}$ at $4^{\circ} \mathrm{C}$. After rinsing, cells were incubated with biotinylated goat anti-rabbit secondary antibody (Vector Laboratories) (1:500 in TBST containing 3\% BSA) for $60 \mathrm{~min}$ at room temperature. Endogenous peroxidase activity was inhibited with $0.6 \%$ hydrogen peroxide in TBS for $30 \mathrm{~min}$ at room temperature. Immunostaining was performed by the avidinbiotinylated complex (Vectastain Elite ABC Kit; Vector Laboratories). Antigen-antibody complex was visualized by 3,3'-diaminobenzidine containing nickel chloride (DAB substrate kit for peroxidase; Vector Laboratories) as chromogen. After staining, coverslips were dehydrated in ascending ethanols, immersed in xylene and mounted on glass microscope slides.

Negative controls were performed by omitting the primary antibody. 3T3-Swiss albino cells treated with the phorbol ester 12-O-tetradecanoylphorbol-13-acetate (TPA) $160 \mathrm{mM}$ were used as positive control for $\mathrm{pERK} 1 / 2$.

Evaluation of immunoreactivity of LNCaP cells. Slides were examined using a Zeiss Axiophot light microscope and a x40 magnification lens. Images from the cells were captured using a Sony XC77 CCD camera connected to a Macintosh IIvX computer (Apple Computer, Cupertino, CA, USA) by means of a Scion LG3 frame grabber (Scion Corporation, Frederick, MA, USA). The intensity of staining reactivity was evaluated on a grey scale ranging from 0 (white) to 255 (black), in 100 cells from at least 5-6 random fields per slide. The sampled cell was outlined by hand on the computer screen and the mean grey level was measured. The background grey value was determined in at least four cell-lacking areas near the sampled cell. The specific mean grey value was calculated by deducting the background grey value. Measurements were performed on slides under constant lighting conditions.

Evaluation of immunoreactivity of $\mathrm{PC}-3$ cells. Owing to the peculiar morphology of the attached PC-3 cells as well as the numerous spherical grape-like aggregates arising from them, an evaluation as described for LNCaP cells was impossible. Therefore, PC-3 cells were counted with a Zeiss Axiophot light microscope and the staining intensity of each MAP kinase was graded as absent, weak, moderate or strong. Two independent observers counted at least 500 cells in 5-10 random fields per slide and the percentage of stained cells at each intensity was determined.

The immunohistochemical analysis was scored in a semiquantitative fashion incorporating both the intensity and distribution of specific staining. Scoring was generated as follows: $[3 \times$ ( $\%$ of strongly stained cells $)]+[2 \times(\%$ of moderately stained cells $)]+[1 \mathrm{x}$ (\% of weakly stained cells $)]$ (14). This gave a possible range of 0-300. Scoring was performed on high-power fields (x400).

Data analysis. For each dose-response curve, at least two proliferation experiments in triplicate were performed. Data of cell growth were expressed as mean \pm SE. All Western blot analyses were conducted at least twice on different occasions, and the most representative results are shown.

Proliferation, Western blotting and PC-3-immunocytochemistry data were analyzed using the Student's t-test to determine the significance of differences between two populations. Immunocytochemical data in $\mathrm{LNCaP}$ cells were analyzed by one-way ANOVA followed by Tukey's multiple comparison test. A value of $\mathrm{p}<0.05$ was always considered statistically significant.

\section{Results}

Cell proliferation. We previously reported that LA, added daily to the culture medium, did not induce any variation in the growth of either LNCaP or PC-3 cells, even at the highest concentration tested $\left(10^{-5} \mathrm{M}\right)$. Nevertheless, in $\mathrm{LNCaP}$ cells at doses of $10^{-11}-10^{-8} \mathrm{M}$, it inhibited the DHT-stimulated growth, which was suppressed by the highest concentrations $\left(10^{-7}-10^{-5} \mathrm{M}\right)$ of the analogue used $(6)$.

In the present study, we focused our attention on the mitogenic effects of EGF $(0.1-50 \mathrm{ng} / \mathrm{ml})$ alone or associated with LA $\left(10^{-11}-10^{-5} \mathrm{M}\right)$ in both models.

In LNCaP cells, plated at the lower density, a 2-day treatment with EGF at concentrations of 25 and $50 \mathrm{ng} / \mathrm{ml}$ determined a statistically significant increase in cell numbers of $20 \%$ with respect to control (not shown). After 4 days, 
A

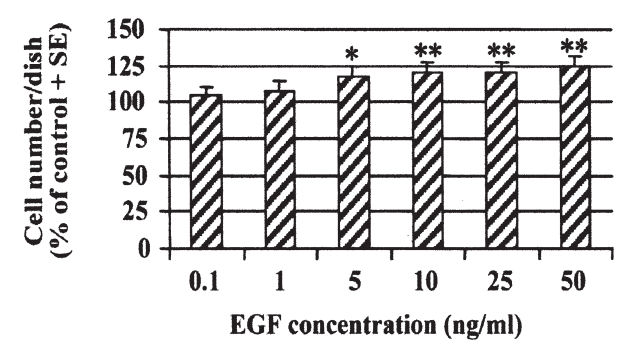

$\mathrm{C}$

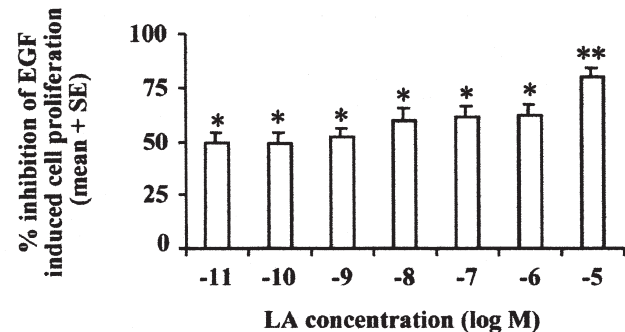

B

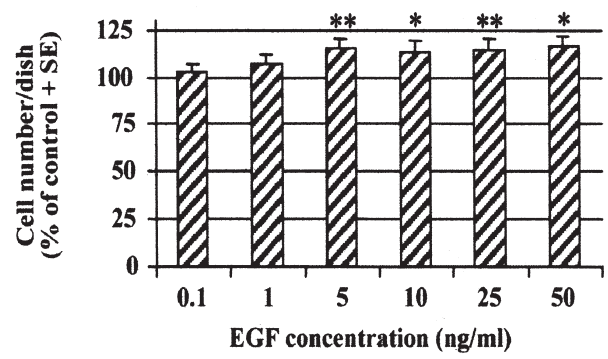

$\mathrm{D}$

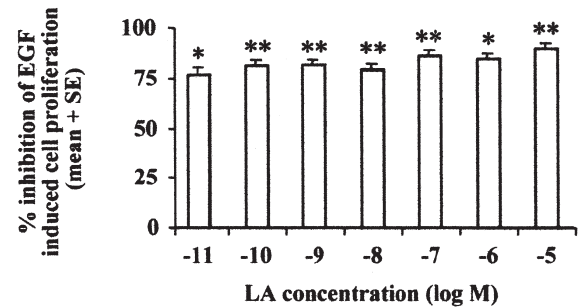

Figure 1. Effect of increasing concentrations of EGF on the growth of LNCaP (A) and PC-3 (B) cells, and effect of increasing concentrations of LA on the EGF-stimulated cell growth of LNCaP (C) and PC-3 (D) cells, after $96 \mathrm{~h}$ of treatment. LNCaP and PC-3 cells were plated at a density of 25,000 cells/ml. Each column represents the mean $\pm \mathrm{SE}(\mathrm{n}=6)$ of the data obtained from two independent experiments run in triplicate. ${ }^{*} \mathrm{p}<0.05$ and ${ }^{* *} \mathrm{p}<0.01$, Student's $\mathrm{t}$-test versus untreated cells (A and B) or versus EGF-treated cells (C and D).

the stimulation of cell growth started from the dose of $5 \mathrm{ng} /$ $\mathrm{ml}$ EGF and reached $\sim 25 \%$ with respect to control at the concentration of $50 \mathrm{ng} / \mathrm{ml}$ (Fig. 1A). The results were similar to those obtained when cells were plated at the higher density (not shown).

In PC-3 cells, seeded at an initial density of 25,000 cells $/ \mathrm{ml}$ of culture medium, no response to EGF was observed after 2 days (not shown), while a statistically significant stimulation of $\sim 15 \%$ was seen at EGF concentrations ranging from 5 to $50 \mathrm{ng} / \mathrm{ml}$ of culture medium after 4 days. No difference in the effectiveness seemed to exist among the concentrations tested (Fig. 1B).

On the basis of these results, we used the concentration of $10 \mathrm{ng} / \mathrm{ml}$ EGF, which stimulated cell growth in both cell lines, to investigate the effect of the combination with LA.

When LNCaP cells were seeded at the lower density, the EGF stimulation was reduced by $50 \%(\mathrm{p}<0.05)$ with $10^{-11} \mathrm{M}$ LA and by $80 \%$ with $10^{-5} \mathrm{M}$ LA (p<0.01) (Fig. 1C). When cells were seeded at 50,000 cells $/ \mathrm{ml}$, it was completely suppressed by concentrations of LA from $10^{-11}$ to $10^{-5} \mathrm{M}(\mathrm{p}<0.001)$ (not shown). In PC-3 cells, LA at both low and high concentrations produced a high reduction of EGF-mitogenic activity (7780\%) (Fig. 1D).

LA was also able to significantly counteract or abolish the DHT or EGF-stimulated proliferation of both LNCaP and PC-3 cells in the conditions in which ERK activity was evaluated (see Materials and methods), as shown in Fig. 2, which refers to the second day of treatment. Moreover, in LNCaP cells, stimulated with EGF, high doses of LA determined a diminution in cell number which decreased below the controls (Fig. 2, middle panel). In all experiments, cell viability was higher than $90 \%$.

Expression of phosphorylation status independent and phosphorylated p44/42 in untreated LNCaP and PC-3 cells. To determine the presence of both phosphorylated and total ERK1/2, LNCaP and PC-3 cells were grown in standard medium until they reached sub-confluence, then they were placed in a low-serum medium which was subsequently changed with serum-free medium to abolish ERK activation due to factors contained in the serum or produced by the cells.

To assess the presence of total ERK1/2 in both androgensensitive and -insensitive prostate cancer cells, a phosphorylation status independent p44/42 MAP kinase antibody was used. Western blot analysis showed that these proteins are highly expressed in both LNCaP and PC-3 cells at the correct molecular weight. No activation of ERK1 and 2 was observed in LNCaP cells, while ERK1 and 2 were constitutively activated and equally expressed in PC-3 cells (Fig. 3, top panel).

Phosphorylated ERK1/2 expression was also evaluated by immunocytochemistry to confirm our findings from Western blot analysis and to determine their intracellular localization. It is important to note that immunocytochemistry could not discriminate between ERK1 and 2 or indicate the rate of activated enzymes with respect to total ERK.

In contrast with data from Western blotting, LNCaP cells displayed a heterogeneous pattern of pERK1/2 staining and, even if most of the immunoreactivity was localized in the 

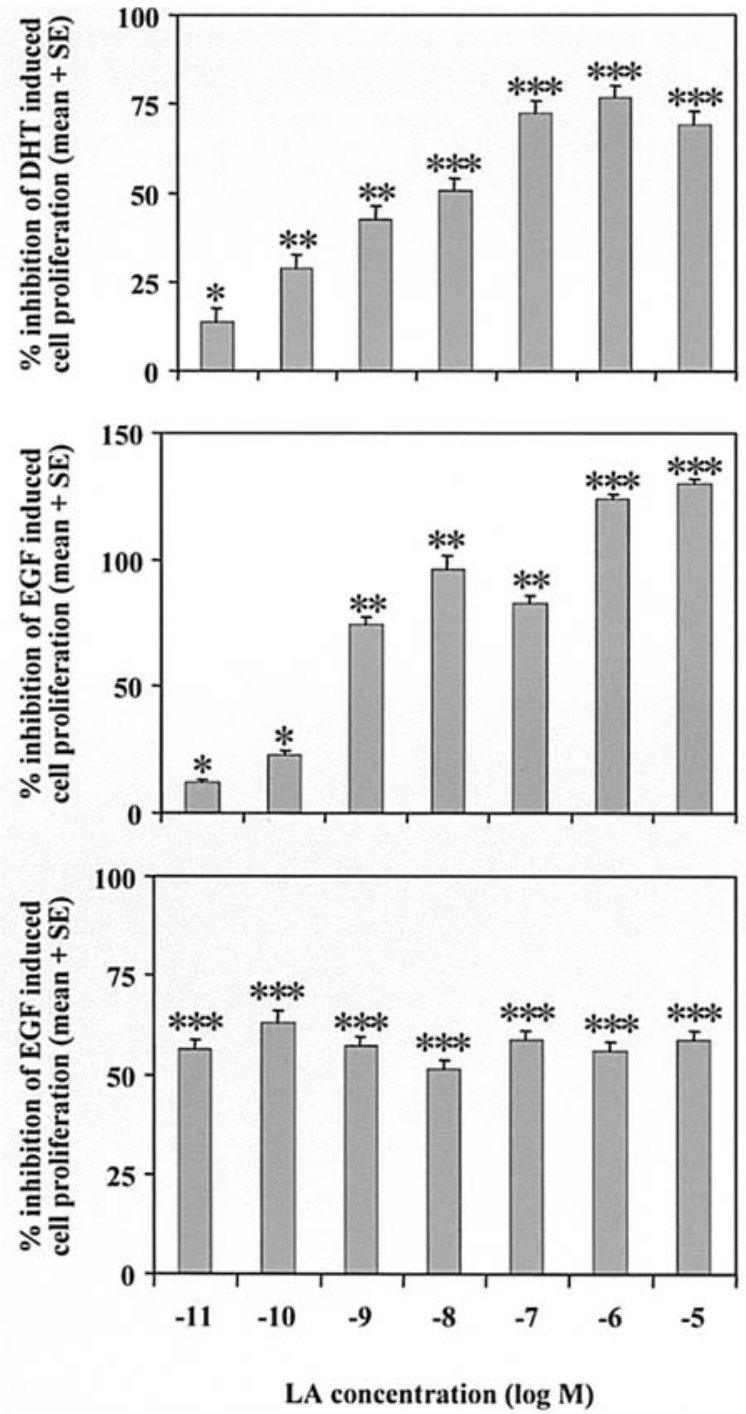

Figure 2. Effect of increasing concentrations of LA on the DHT- (top panel) or EGF-stimulated cell growth of LNCaP cells (middle panel) and PC-3 cells (bottom panel) after $48 \mathrm{~h}$ of treatment. Cells were cultured in the same conditions used to determine ERK activation (for more details, see Materials and methods). Each column represents the mean $\pm \mathrm{SE}(\mathrm{n}=6)$ of the data obtained from two independent experiments run in triplicate. ${ }^{*} \mathrm{p}<0.05$, ${ }^{* *} \mathrm{p}<0.01$ and ${ }^{* * *} \mathrm{p}<0.001$, Student's t-test versus DHT- or EGF-treated cells.

nucleus, it was also observed in the cytoplasm in many cells, as depicted in Fig. 3 (bottom panel). The same pattern of immunoreactivity was observed in PC-3 cells (Fig. 3, bottom panel). In the negative controls, no staining was present (Fig. 3, bottom panel).

ERK activity in LNCaP cells treated with hormones and EGF Western blots indicated that the addition of DHT or LA to LNCaP cells did not promote ERK activation (data not shown). Otherwise, some modifications were found by using immunocytochemical analysis. In fact, after $10 \mathrm{~min}$ of treatment with $10^{-9}$ M DHT, an increase of $16.7 \%(\mathrm{p}<0.001)$ in the intensity of the reaction compared to the control was observed (Fig. 4). Treatment with $10^{-11}$ or $10^{-6} \mathrm{M}$ LA alone did not change the pERK1/2 expression (not shown).

On the contrary, the combination of $10^{-11}$ or $10^{-6} \mathrm{M}$ LA with DHT, determined a slight but statistically significant
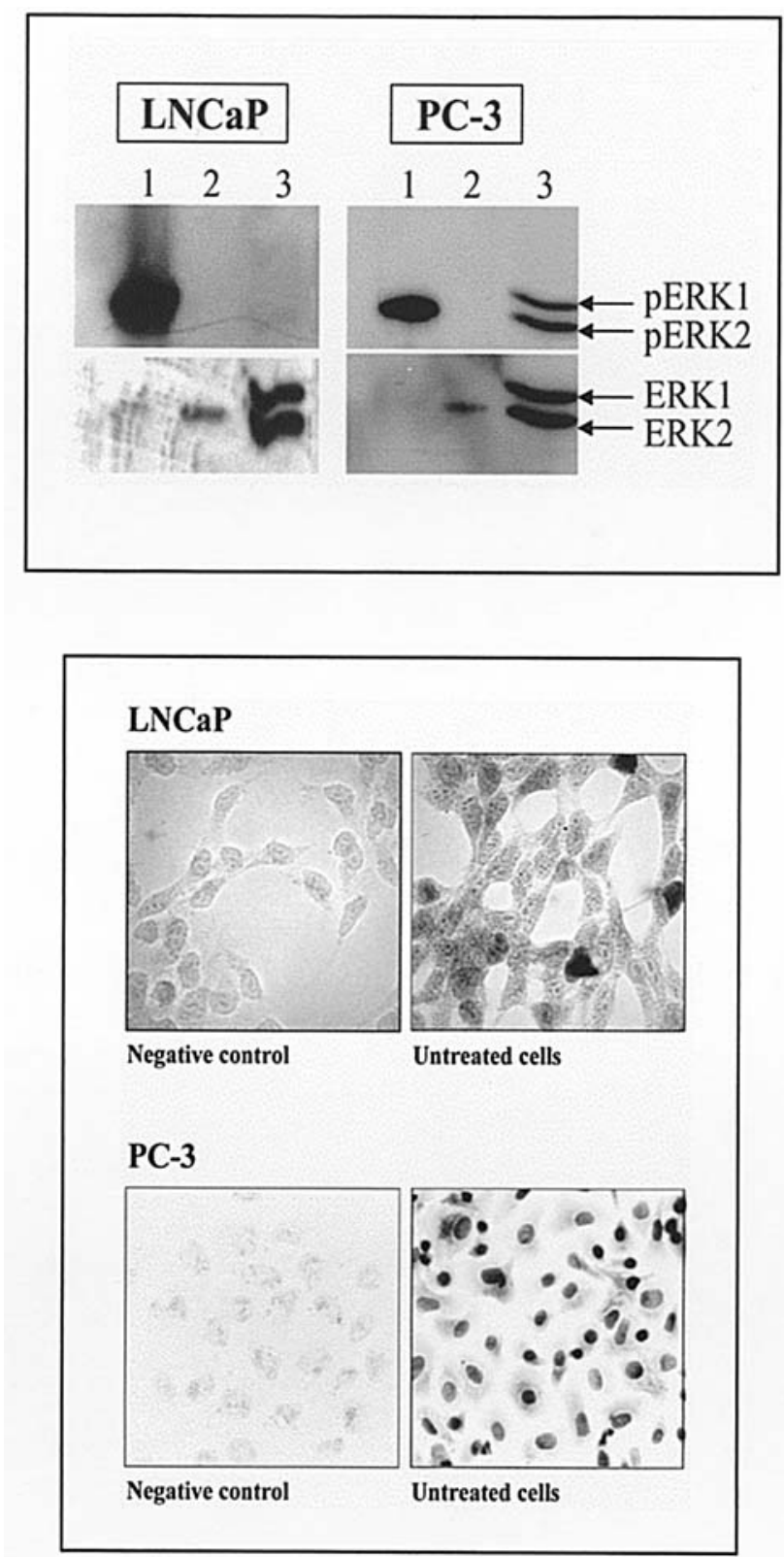

Figure 3. Top panel, Western blot analysis of basal expression of ERK1/2 in LNCaP and PC-3 cells. Positive control (lane 1), negative control (lane 2), cell lysate (lane 3). Bottom panel, immunocytochemical staining for pERK1/2 in LNCaP and PC-3 cells using anti-phospho-p44/42 MAP kinase, Thr202/Tyr204 polyclonal antibody. Negative controls were obtained in the absence of primary antibody. Original magnification x400.

$(\mathrm{p}<0.001)$ reduction $(13.3 \%$ and $11.9 \%$ respectively), in the expression of ERK1/2 obtained with the androgen alone (Fig. 4). The stimulation induced by DHT was substantially suppressed. Similar results were seen when cells were pretreated with the analogue and then exposed to androgen. No relevant modification of staining was observed at the other times examined (data not shown).

There was a substantial coincidence of the results obtained by both Western blotting and immunocytochemistry when cells were exposed to EGF alone or in combination with LA.

The time course of ERK activation was examined by Western blotting in LNCaP cells stimulated with EGF for multiple time points, ranging from 5 min to $4 \mathrm{~h}$. ERK activation was detected early (5 min after the initiation of EGF treatment), 


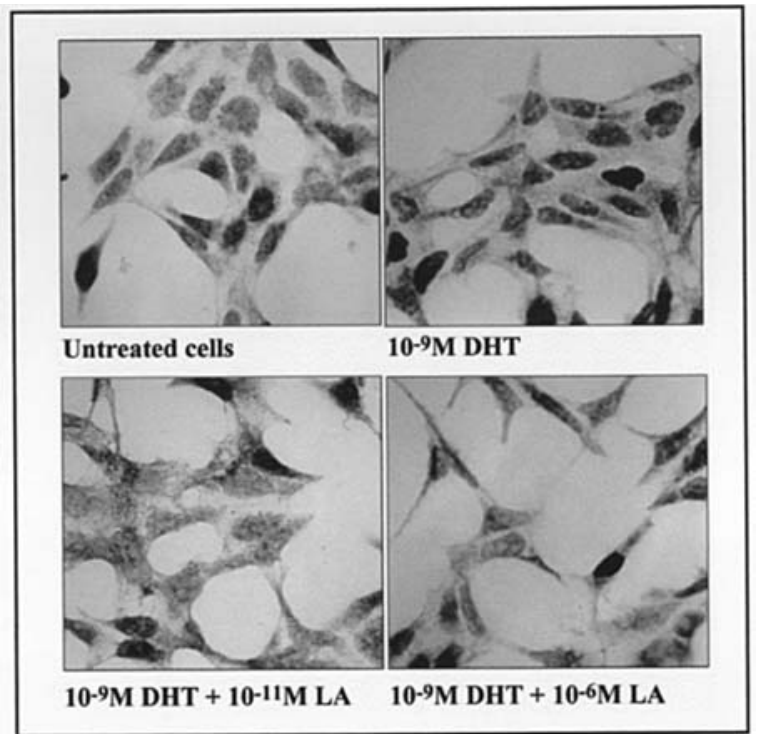

Figure 4. Immunocytochemical staining for pERK $1 / 2$ in $\mathrm{LNCaP}$ cells using anti-phospho-p44/42 MAP kinase, (Thr202/Tyr204) polyclonal antibody. Immunocytochemistry was performed after 10 min of treatment with $10^{-9} \mathrm{M}$ DHT, $10^{-9} \mathrm{M}$ DHT plus $10^{-11} \mathrm{M}$ LA, $10^{-9} \mathrm{M}$ DHT plus $10^{-6} \mathrm{M}$ LA or in untreated cells. Original magnification $\mathrm{x} 400$
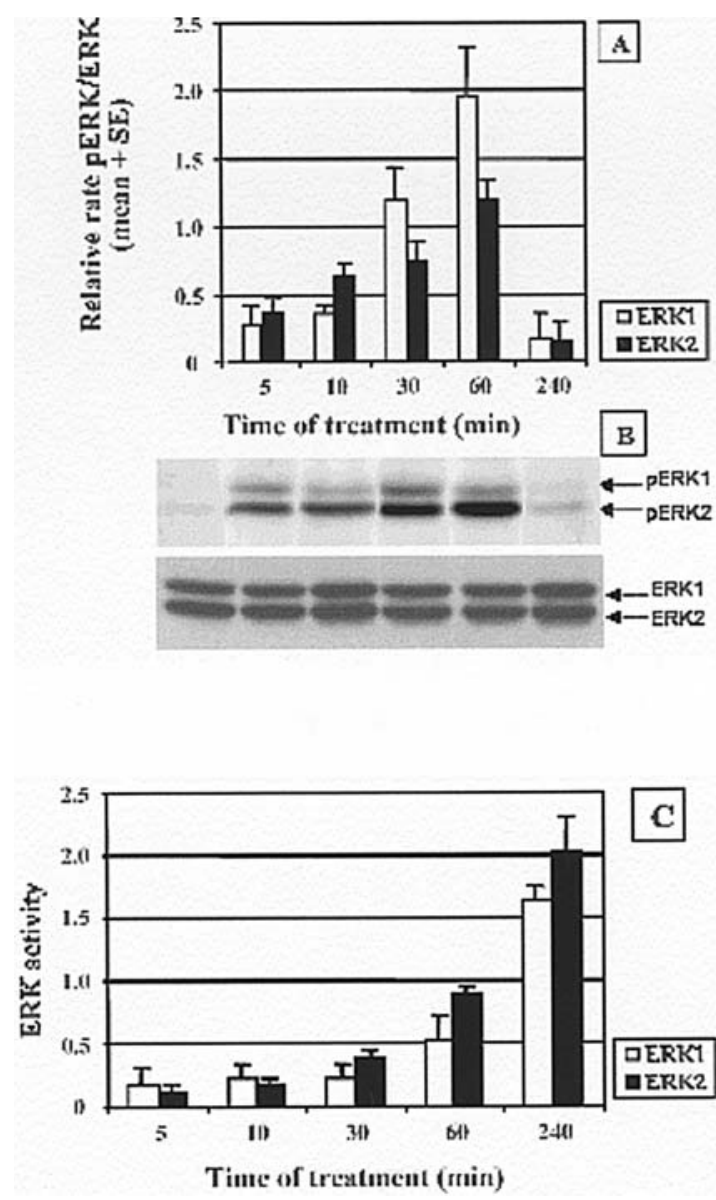

Figure 5. Time course (from 5 to $240 \mathrm{~min}$ ) of ERK activation in LNCaP cells treated with $10 \mathrm{ng} / \mathrm{ml}$ EGF. (A) Total ERK and pERK levels were analyzed by immunoblot assay. pERK levels were quantified by densitometry and standardized against the levels of total ERK per sample. (B) Immunoblot from a representative experiment. Untreated cells (lane 1). (C) Effect of the inhibitor on ERK activation induced by EGF. In this case columns represent the ratio of values obtained in cells treated with the inhibitor, AG1478, normalized against the values from EGF-treated cells set as 1 .
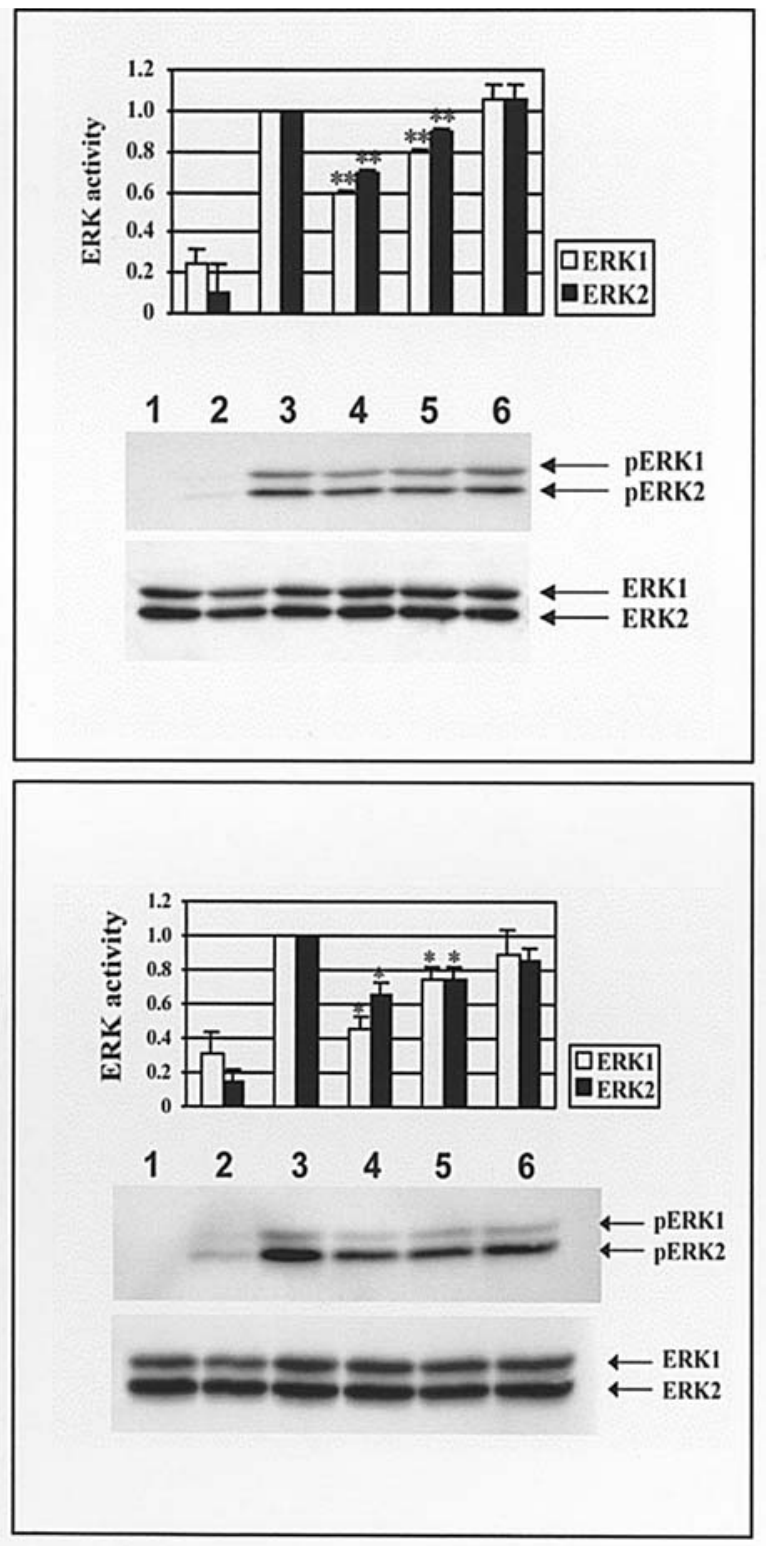

Figure 6. Western blot analysis of pERK and total ERK expression in LNCaP cells exposed to different treatments for $5 \mathrm{~min}$ (top panel) or for 10 min (bottom panel). Total ERK and pERK levels were analyzed by immunoblot assay. pERK levels were quantified by densitometry and standardized against the levels of total ERK per sample. The resulting values were normalized against the values from EGF-treated cells set as 1. Values are the mean $\pm \mathrm{SE}$ of two individual experiments. Immunoblot from a representative experiment is shown below. Untreated cells (lane 1), cells pre-exposed to the inhibitor, AG1478, and then treated with $10 \mathrm{ng} / \mathrm{ml}$ EGF (lane 2), $10 \mathrm{ng} / \mathrm{ml}$ EGF (lane 3), $10 \mathrm{ng} / \mathrm{ml}$ EGF plus $10^{-11} \mathrm{M} \mathrm{LA}$ (lane 4), $10 \mathrm{ng} / \mathrm{ml}$ EGF plus $10^{-6} \mathrm{M} \mathrm{LA}$ (lane 5), $10 \mathrm{ng} / \mathrm{ml}$ EGF plus $10^{-5} \mathrm{M}$ LA (lane 6). ${ }^{* *} \mathrm{p}<0.01$, Student's $\mathrm{t}$ test versus EGF-treated cells.

ERK2 being more expressed than ERK1. The activity peaked by $60 \mathrm{~min}$, and decreased over the next $4 \mathrm{~h}$. Fig. $5 \mathrm{~A}$ refers to data from three separate curves and a representative blot is shown (Fig. 5B). To provide evidence that EGF receptor phosphorylation was required for ERK activation, cells were 30-min pre-treated with the specific inhibitor of the tyrosine kinase of the EGF receptor (300 nM AG1478). After 5 min, a 90\% inhibition of EGF-induced ERK activity was observed which gradually diminished until 30 min or $1 \mathrm{~h}$. The AG1478 effect disappeared after $4 \mathrm{~h}$ (Fig. 5C), when ERK activation was higher than that observed in cells treated with EGF alone. 

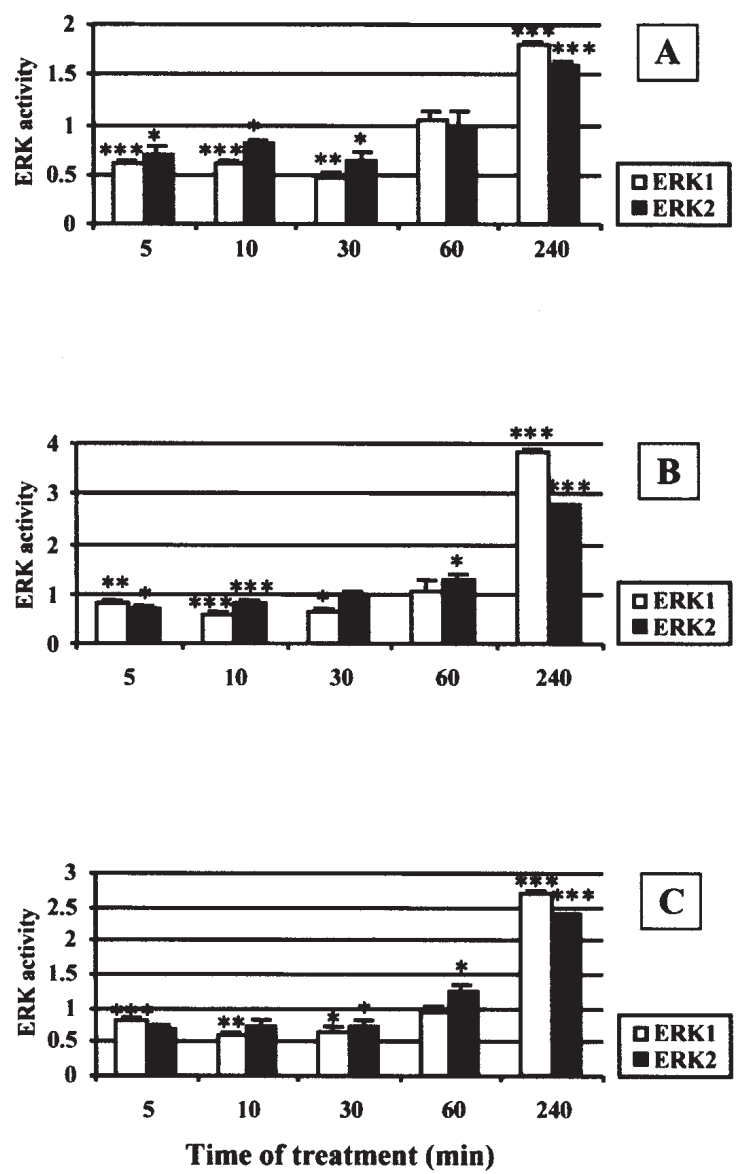

Figure 7. Effect of LA on ERK activation induced by EGF in LNCaP cell line. Cells were pre-exposed to $10^{-11} \mathrm{M}$ (A), $10^{-6} \mathrm{M}$ (B) or $10^{-5} \mathrm{M}$ (C) LA and then treated (from 5 to $240 \mathrm{~min}$ ) with $10 \mathrm{ng} / \mathrm{ml}$ EGF. Total ERK and pERK levels were analyzed by immunoblot assay. pERK levels were quantified by densitometry and standardized against the levels of total ERK per sample. The resulting values were normalized against the values from EGF-treated cells set as 1 . Values are the mean $\pm \mathrm{SE}$ of two individual experiments. ${ }^{*} \mathrm{p}<0.05,{ }^{* *} \mathrm{p}<0.01,{ }^{* * *} \mathrm{p}<0.001$; Student's t-test versus EGF-treated cells.

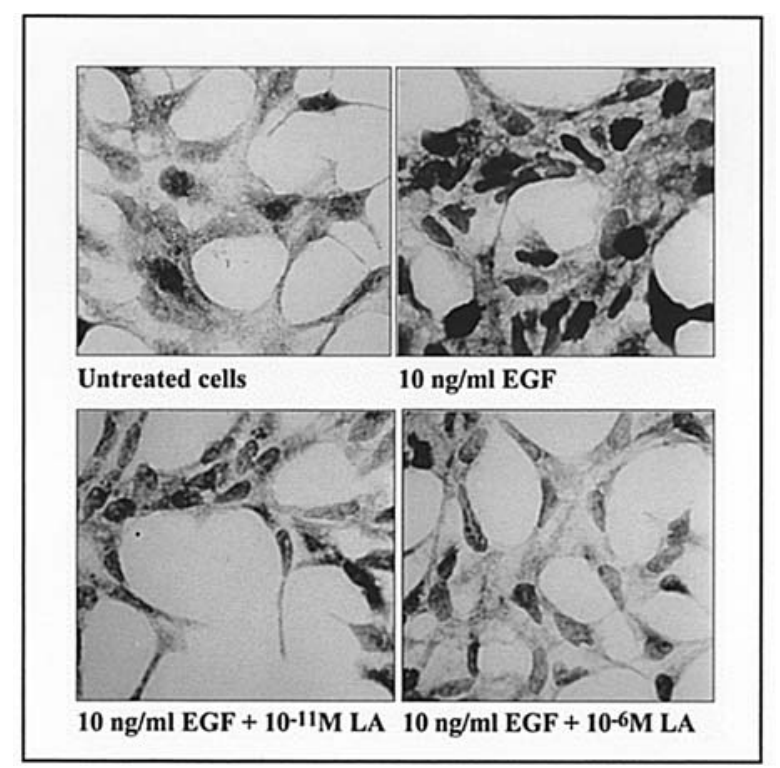

Figure 8. Immunocytochemical staining for pERK $1 / 2$ in LNCaP cells using anti-phospho-p44/42 MAP kinase, Thr202/Tyr204 polyclonal antibody. Immunocytochemistry was performed after $30 \mathrm{~min}$ of treatment with $10 \mathrm{ng} / \mathrm{ml}$ EGF, $10 \mathrm{ng} / \mathrm{ml}$ EGF plus $10^{-11} \mathrm{M}$ LA, $10 \mathrm{ng} / \mathrm{ml}$ EGF plus $10^{-6} \mathrm{M}$ LA or in untreated cells. Original magnification $\mathrm{x} 400$
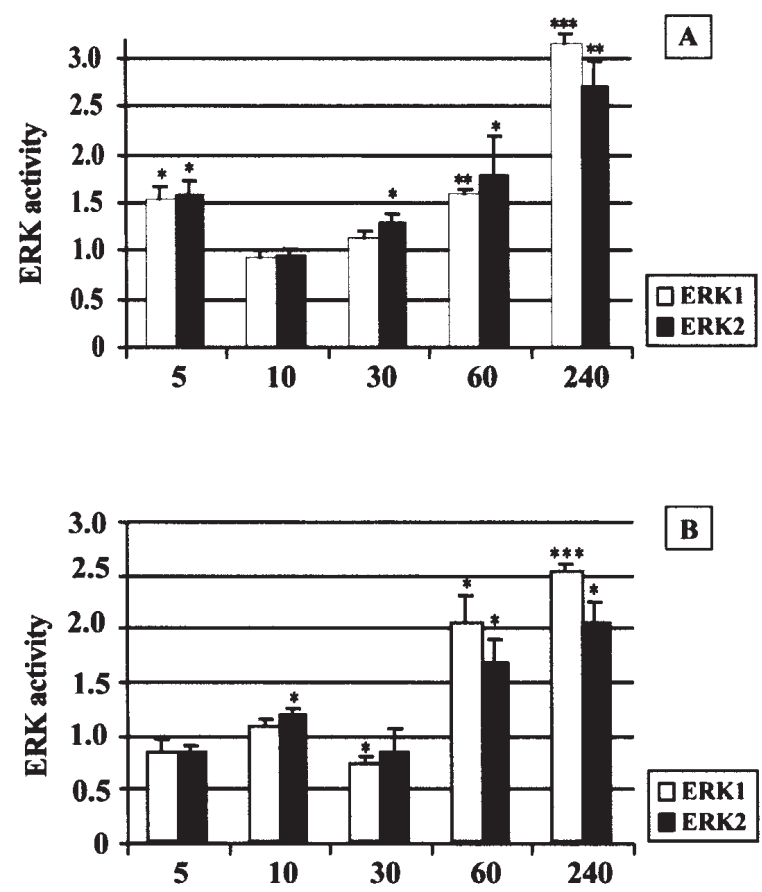

Time of treatment (min)

Figure 9. Time course (from 5 to $240 \mathrm{~min}$ ) of ERK activation in PC-3 cells treated with $10^{-11} \mathrm{M}$ (A) and $10^{-5} \mathrm{M}$ (B) LA. Total ERK and pERK levels were analyzed by immunoblot assay. pERK levels were quantified by densitometry and standardized against the levels of total ERK per sample. The resulting values were normalized against the values from untreated cells set as 1 . Values are the mean $\pm \mathrm{SE}$ of two individual experiments. ${ }^{*} \mathrm{p}<0.05$, ${ }^{* *} \mathrm{p}<0.01,{ }^{* * *} \mathrm{p}<0.001$; Student's t-test versus control cells.

To assess the role of ERK activation in the LA reduction of cell proliferation induced by EGF, LNCaP cells were treated with LA plus EGF or were pre-incubated for 15 min with the analogue prior to EGF exposure.

When LA at doses of $10^{-11} \mathrm{M}$ and $10^{-6} \mathrm{M}$ was combined with EGF, a reduction in ERK activation was seen. This effect was evident with both of the LA concentrations used after $5 \mathrm{~min}$, but the lower dose of the analogue was more effective; $30 \%$ inhibition for ERK2 and $40 \%$ for ERK1 (Fig. 6, top panel).

The analogue at the lower dose continued to determine, after $10 \mathrm{~min}$, a higher reduction in ERK activation (38-60\%), (Fig. 6, bottom panel). The reduction produced by the analogue in ERK activation persisted after 30 and 60 min (data not shown). It is worth mentioning that the highest dose of LA employed $\left(10^{-5} \mathrm{M}\right)$ did not affect ERK activity.

Of note, the signal given by Western blotting referring to cells exposed to EGF was almost undetectable after $4 \mathrm{~h}$, but it seemed to be nullified by the analogue (not shown).

If $\mathrm{LNCaP}$ cells were pre-incubated for $15 \mathrm{~min}$ with the analogue and then exposed to EGF, a trend similar to that produced by AG1478 was observed. In fact, LA was able to counteract the EGF-induced ERK phosphorylation within 5-30 $\min$ ( $\sim 30 \%$ inhibition). The effect of the analogue disappeared after prolonged treatment $(60 \mathrm{~min})$ and, after $4 \mathrm{~h}$, ERK phosphorylation exceeded that seen with EGF alone. In this condition, $10^{-5} \mathrm{M}$ LA produced a reduction in ERK activation with a behaviour similar to that displayed by the other concentrations after 5-30 min of treatment (Fig. 7). 
Similar results were obtained with immunocytochemistry. Fig. 8 shows a representative experiment after $30 \mathrm{~min}$ of exposure to different compounds.

ERK activity in PC-3 cells untreated or treated with LA and $E G F$. In PC-3 cells, which express basal levels of pERK, the analogue generally determined an increase in this activity. The enhancement in phosphorylation status, induced by both the concentrations used, peaked after $4 \mathrm{~h}$ of exposure $(>100 \%)$ (Fig. 9).

In PC-3 cells, the addition of $10 \mathrm{ng} / \mathrm{ml}$ EGF resulted in a rapid stimulation of ERK phosphorylation. The enhancement was evident after $5 \mathrm{~min}$, peaked after $60 \mathrm{~min}$, and persisted until $4 \mathrm{~h}$ (Fig. 10A and B).

As with LNCaP cells, pre-exposure of PC-3 cells to AG1478 counteracted the EGF-stimulated activity. This was evident after $5 \mathrm{~min}$ (>70\% inhibition), persisted until $60 \mathrm{~min}$ (40-60\%), and was lost after $4 \mathrm{~h}$ (Fig. 10C).

When LA and EGF were combined, a more pronounced increase in ERK activity was generally observed, with respect to that observed with EGF or LA alone, using both Western blot analysis and immunocytochemistry. The enhancement was observed in both modalities of treatment (simultaneous or in sequence) and, in some cases, ERK phosphorylation was $>5$-fold with respect to control after $1 \mathrm{~h}$ of treatment. Fig. 11 refers to Western blotting (top panel) and immunocytochemistry (bottom panel) results, after $60 \mathrm{~min}$ of treatment.

Of note, there was no change in the localization of immunostaining in both $\mathrm{LNCaP}$ and PC-3 cells due to the different treatments.

\section{Discussion}

The present study demonstrates that $\mathrm{LNCaP}$ and PC-3 cells respond to EGF with an increase in cell proliferation, as measured by cell counting. The stimulation that we obtained in our experiments concerning $\mathrm{LNCaP}$ cells is lower than that observed in the majority of studies, which show that the increase in cell number was generally $>25 \%$ with respect to control $(10,12,15,16)$.

The evidence in the literature concerning EGF activity in PC-3 cells remains contradictory and no clear effect emerges. Some authors described an increase $(4,10,17-19)$ in cell growth after EGF treatment while, in certain cases, no effect on proliferation was observed $(17,20,21)$. The divergent responses to EGF in PC-3 cells and the differences in the mitogenic effect in LNCaP cells may reflect the differences in cell passages, cell density, culture conditions or EGF concentrations used.

The increase in cell number found in PC-3 cells after EGF exposure is similar to that which we reported in our previous manuscript (4).

Consistent with other data in the literature in which other analogues or other models have been used $(22,23)$, Leuprorelin acetate inhibited DHT- and EGF-induced proliferation in both LNCaP and PC- 3 cell lines, also when very low concentrations are used $\left(10^{-11} \mathrm{M}\right)$ and in all conditions tested; i.e. presence of $5 \%$ or $0.5 \%$ CH-FBS.

Many reports indicate that the MAP kinase pathway may be involved in the mitogenic action of hormones and growth factors in prostate cancer as well as in other kinds of tumour.
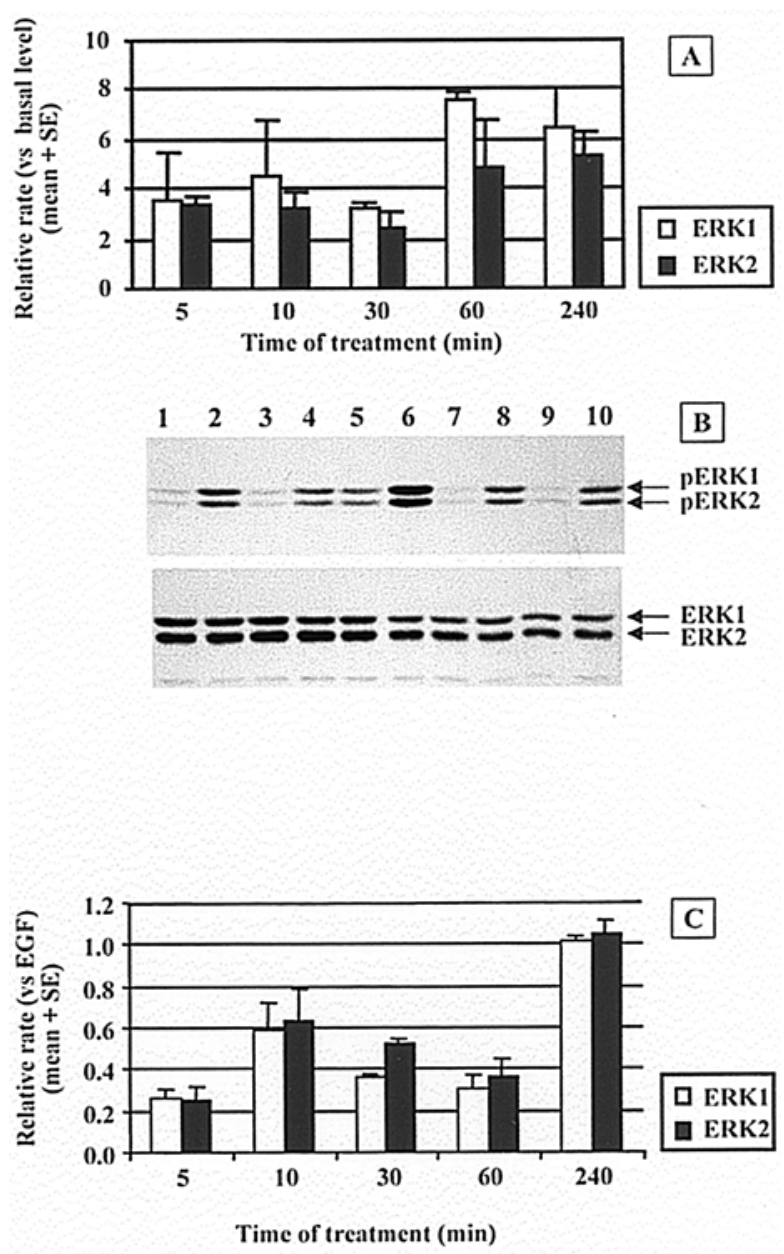

Figure 10. Time course (from 5 to $240 \mathrm{~min}$ ) of ERK activation in PC-3 cells treated with $10 \mathrm{ng} / \mathrm{ml}$ EGF. (A) Total ERK and pERK levels were analyzed by immunoblot assay. pERK levels were quantified by densitometry and standardized against the levels of ERK per sample. The resulting values were normalized against the values from untreated cells set as 1. Values are the mean \pm SE of two individual experiments. (B) Immunoblotting from a representative experiment. Untreated cells (lanes 1, 3, 5, 7 and 9), EGF-treated cells (lanes 2, 4, 6, 8 and 10). (C) Effect of the inhibitor, AG1478, on ERK activation induced by EGF.

To establish the role of the modulation of kinase phosphorylation in the ability of LA to counteract the stimulation of cell growth produced by DHT or EGF, ERK activity was evaluated in LNCaP and PC-3 cells untreated or after different treatments.

Our data from Western blotting clearly demonstrate that untreated androgen-sensitive LNCaP cells in serum-free conditions did not show any signal of pERK, while a basal activation was present in untreated PC-3 cells in the same culture conditions, in agreement with the majority of reports in the literature $(9,15,24-29)$.

In contrast with results from Western blotting, immunocytochemistry evaluation revealed specific staining localized in the nuclei as well as cytoplasm of $\mathrm{LNCaP}$ cells, in agreement with the scarce data available $(15,30,31)$, even if papers by the cited authors lack details or figures. There is no information in the literature concerning immunocytochemical analysis of pERK in PC-3 cells.

To our knowledge, this is the first report that shows ERK activity in PC-3 cells and in which detailed information is reported about pERK in LNCaP cells determined by immunocytochemistry. 

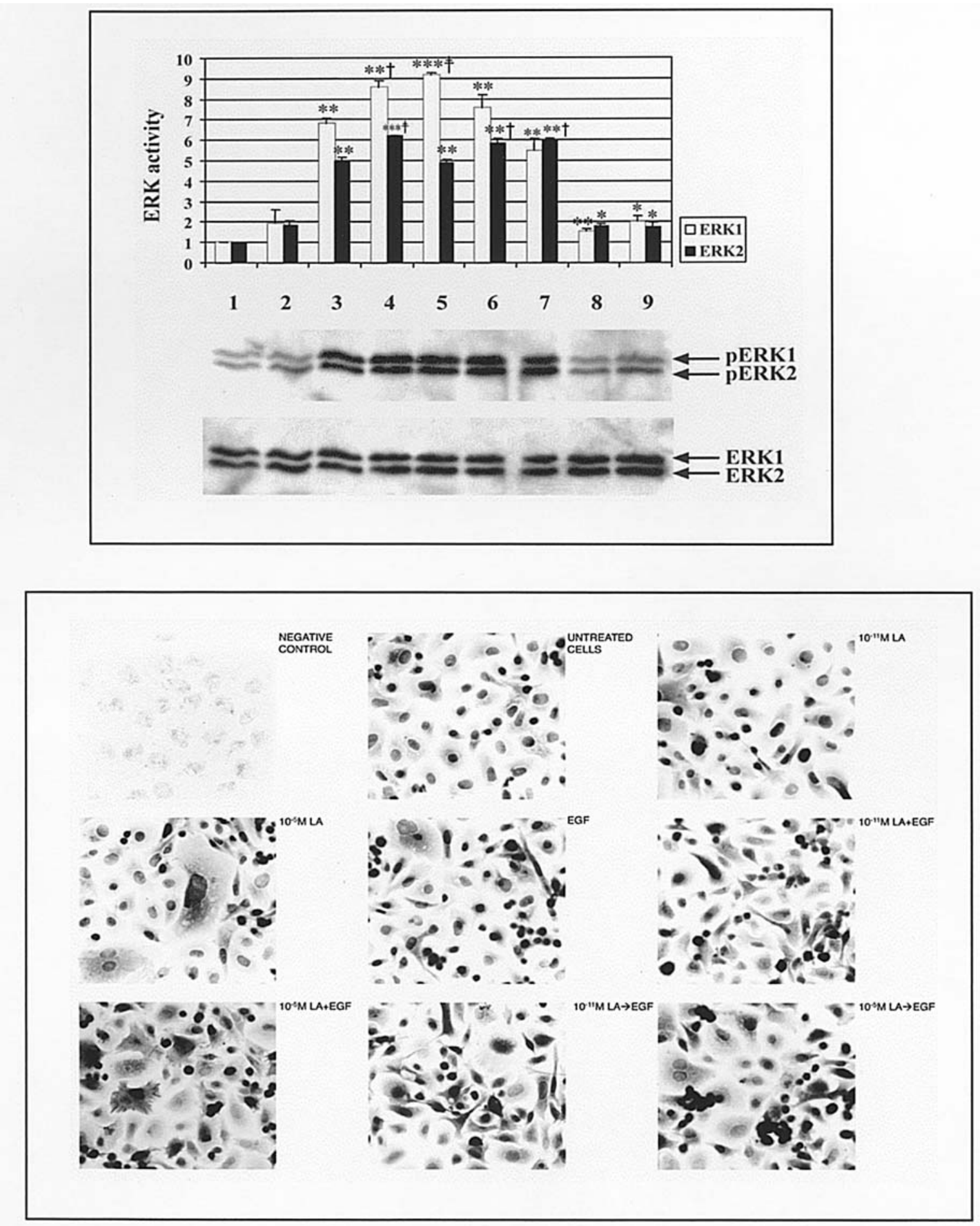

Figure 11. Top panel, Western blot analysis of pERK and total ERK expression in PC-3 cells exposed to different treatments for 60 min. Total ERK and pERK levels were analyzed by immunoblot assay. pERK levels were quantified by densitometry and standardized against the levels of total ERK per sample. The resulting values were normalized against the values from untreated cells set as 1 . Values are the mean \pm SE of two individual experiments. Immunoblotting from a representative experiment is shown below. Untreated cells (lane 1), cells pre-exposed to inhibitor (AG1478) and then treated with $10 \mathrm{ng} / \mathrm{ml}$ EGF (lane 2), $10 \mathrm{ng} / \mathrm{ml}$ EGF (lane 3), $10 \mathrm{ng} / \mathrm{ml}$ EGF plus $10^{-11} \mathrm{M} \mathrm{LA}$ (lane 4), $10 \mathrm{ng} / \mathrm{ml} \mathrm{EGF}$ plus $10^{-5} \mathrm{M}$ LA (lane 5), cells pre-exposed to $10^{-11} \mathrm{M} \mathrm{LA}$ (lane 6) or 10-5 M LA (lane 7), and then treated with $10 \mathrm{ng} / \mathrm{ml}$ EGF, $10^{-11} \mathrm{M} \mathrm{LA}$ (lane 8), $10^{-5} \mathrm{M}$ LA (lane 9). ${ }^{*} \mathrm{p}<0.05,{ }^{* *} \mathrm{p}<0.01$; Student's t-test versus control cells. ${ }^{\dagger} \mathrm{p}<0.05$, ${ }^{\ddagger} \mathrm{p}<0.01$, Student's t-test versus EGF treated cells. Bottom panel, immunocytochemical staining for pERK1/2 in PC-3 cells using anti-phospho-p44/42 MAP kinase, Thr202/Tyr204 polyclonal antibody. Immunocytochemistry was performed after 60 min with the treatments reported above. Negative control was obtained in the absence of primary antibody. Original magnification $\mathrm{x} 400$.

We assessed that LA alone did not determine ERK activation in LNCaP cells; on the other hand, the analogue did not modify cell growth. The slight increase in pERK expression that we observed by immunocytochemistry after DHT treatment could not be confirmed by Western blotting, hence it is not possible to draw any conclusions in agreement with data in the literature. In fact, ERK activation following androgen treatment is a point of controversy among various authors, some of whom found an increase $(9,25,32)$ while others reported no variation $(10,27,31)$. 
On the other hand, EGF determined an increase in ERK activation with both Western blotting and immunocytochemistry as well as mitogenic activity in LNCaP cells and our data are in agreement with those reported in the literature $(10,15,24,27,30,31,33)$.

Consistent with results obtained by other authors, the decrease in ERK activation following AG1478 treatment supports the idea that EGF receptor tyrosine kinase activity may be an intermediate in rapid EGF-induced ERK activation (10).

More interestingly, we found that LA, particularly at a low concentration, induced a reduction in ERK activation produced by EGF after a brief treatment. However, the effect was more evident concerning ERK1, as revealed by Western blot analysis. A reduction of ERK activity induced by DHT was seen by immunocytochemistry.

Our findings are in complete agreement with a report by Emons et al (23), who showed that the 5-fold increase in ERK activity induced by EGF in ovarian and endometrial cancer cell lines was nullified by pre-exposure to triptorelin, another GnRH agonist. It is worth mentioning that EGF produced an increase in cell numbers that was $<30 \%$ in 2 of the models used.

As far as PC-3 cells are concerned, EGF determined an increase in ERK activity, as expected, in accordance with other authors $(10,24)$. In spite of the analogue inefficacy on cell proliferation, an induction of ERK activity occurred after 60 and $240 \mathrm{~min}$ of LA treatment. Still more surprising was the pERK increase produced by the LA/EGF combination, whereas the analogue showed antagonizing properties on EGF mitogenic activity. It may be hypothesized that both these events may reflect a protracted ERK activation after LA treatment. Transient activation of MAP kinase is thought to be associated with cellular proliferation, whereas prolonged activation seems to be involved in differentiation. In this context, Reiss et al (34) observed that, in pituitary $\alpha \mathrm{T} 3-1$ cells, EGF, TPA and triptorelin induced ERK activation. Maximal activity after triptorelin and TPA treatment persisted for $60 \mathrm{~min}$ and dropped to near-basal levels only after 2-4 h of incubation whereas activation by EGF was shorter and dropped to basal levels within 20 min. Recently, Kraus et al (35) have shown that triptorelin induced ERK activation and, at the same time, apoptosis in a human androgen unresponsive prostate cancer cell line (DU-145). Moreover, Kimura et al (36) demonstrated that LA, which had antiproliferative activity in a human ovarian cancer cell line, Caov-3, activated ERKs and its effect was sustained until $24 \mathrm{~h}$. Finally, it has been reported that other agents, such as phenethyl isothiocyanate, which has apoptotic activity, induce prolonged activation of ERK1/2 in PC-3 cells (26).

There would seem to be a difference concerning the involvement of ERK activation in the effect of LA on cell proliferation of LNCaP and PC-3 cells stimulated by mitogens. This might be due to the different expression of pERK1 and 2 in these cell lines. In fact, PC-3 cells expressed constitutive ERK1/2 activation while LNCaP cells did not. Recently, Unni et al (9) reported that a constitutively active kinase pathway in LNCaP cells is associated with their transition to androgen independence. The presence of this constitutively active kinase pathway is related to unresponsiveness to manipulation with androgen receptor agonists or antagonists. Of note, in our experience, pERK2 was more expressed than pERK1 in LNCaP cells while, in PC-3 cells, both proteins were expressed at the same level. The role of the two ERK isoforms remains to be clarified and few papers have been dedicated to this topic. Reiss et al (34) showed that a GnRH analogue preferentially activated the ERK1 isoform, whereas other compounds (i.e. doxorubicin) were reported to expecially activate ERK2 (37). In some cases, ERK1 might be involved in the regulation of differentiated cellular functions while ERK2 might mainly regulate cell proliferation (35) but, in other cases, ERK1 activation seems to be an important determinant in cell transformation (38). Moreover, ERK2 activation may result in growth arrest and apoptosis (37) or in increased proliferation (39).

In conclusion, the findings presented in this manuscript indicate that the inhibitory effect of GnRH analogues in the presence of mitogens may be linked to interference with growth factor signal transduction. The ERK pathway seems to be involved in this phenomenon, the activation being dependent on the cell characteristics (androgen-responsiveness or androgen-unresponsiveness). The possibility of obtaining the mentioned effects in vitro with a very low concentration of LA suggests that these effects might also be obtained in vivo, which seems interesting in view of the potential use of the analogue in hormone-refractory prostate cancer.

\section{Acknowledgements}

This study was supported by a grant from Takeda Italia Farmaceutici. The technical assistance of Dr Susanna Capucci and Manila Boca are acknowledged.

\section{References}

1. Shalev E and Leung PC: Gonadotropin-releasing hormone and reproductive medicine. J Obstet Gynaecol Can 25: 98-113, 2003.

2. Florio S, Pagnini U, Crispino A, Pacilio C, Crispino L and Giordano A: GnRH and steroids in cancer. Front Biosci 7: d1590-d1608, 2002.

3. Schally AV, Comaru-Schally AM, Nagy A, Kovacs M, Szepeshazi K, Plonowski A, Varga JL and Halmos G: Hypothalamic hormones and cancer. Front Neuroendocrinol 22: 248-291, 2001.

4. Sica G, Iacopino F, Settesoldi D and Zelano G: Effect of leuprorelin acetate on cell growth and prostate-specific antigen gene expression in human prostatic cancer cells. Eur Urol 35 (suppl 1): 2-8, 1999.

5. Sica G, Zelano G, Settesoldi D and Iacopino F: Regulation of prostate-specific antigen gene expression by an LH-RH analogue in human prostatic cells. Anticancer Res 23: 1283-1287, 2003.

6. Angelucci C, Iacopino F, Lama G, Capucci S, Zelano G, Boca M, Pistilli A and Sica G: Apoptosis-related gene expression affected by a GnRH analogue without induction of programmed cell death in LNCaP cells. Anticancer Res 24: 2729-2738, 2004.

7. Zhang W and Liu HT: MAPK signal pathways in the regulation of cell proliferation in mammalian cells. Cell Res 12: 9-18, 2002.

8. Hunter T: Protein kinases and phosphatases: The yin and yang of protein phosphorylation and signalling. Cell 80: 225-236, 1995.

9. Unni E, Sun S, Nan B, McPhaul MJ, Cheskis B, Mancini MA and Marcelli M: Changes in androgen receptor nongenotropic signaling correlate with transition of $\mathrm{LNCaP}$ cells to androgen independence. Cancer Res 64: 7156-7168, 2004.

10. Guo C, Luttrell LM and Price DT: Mitogenic signaling in androgen sensitive and insensitive prostate cancer cell lines. J Urol 163: 1027-1032, 2000. 
11. Moretti RM, Montagnani Marelli M, Dondi D, Poletti A, Martini L, Motta M and Limonta P: Luteinizing hormonereleasing hormone agonists interfere with the stimulatory actions of epidermal growth factor in human prostatic cancer cell lines, LNCaP and DU 145. J Clin Endocrinol Metab 81: 3930-3937, 1996.

12. Eaton CL, Davies P, Harper M, France T, Rushmere N and Griffiths K: Steroids and the prostate. J Steroid Biochem Mol Biol 40: 175-183, 1991.

13. Peterson GL: A simplification of the protein assay method of Lowry et al. which is more generally applicable. Anal Biochem 83: 346-356, 1977.

14. Sasaki H, Nio M, Iwami D, Funaki N, Ohi R and Sasano H: Cytokeratin subtypes in biliary atresia: immunohistochemical study. Pathol Int 51: 511-518, 2001.

15. Jones HE, Barrow D, Dutkowski CM, Goddard L, Smith C, Harper ME and Nicholson RI: Effect of an EGF-R selective tyrosine kinase inhibitor and an anti-androgen on LNCaP cells: identification of divergent growth regulatory pathways. Prostate 49: 38-47, 2001.

16. Hobisch A, Fiechtl M, Sandahl-Sorensen B, Godoy-Tundidor S, Artner-Dworzak E, Ramoner R, Bartsch G and Culig Z: Prostate cancer cells generated during intermittent androgen ablation acquire a growth advantage and exhibit changes in epidermal growth factor receptor expression. Prostate 59: 401-408, 2004.

17. Desruisseau S, Ghazarossian-Ragni E, Chinot O and Martin PM: Divergent effect of TGFbeta1 on growth and proteolytic modulation of human prostatic-cancer cell lines. Int J Cancer 66: 796-801, 1996

18. Jones HE, Eaton CL, Barrow D, Dutkowski CM, Gee JM and Griffiths K: Comparative studies of the mitogenic effects of epidermal growth factor and transforming growth factor-alpha and the expression of various growth factors in neoplastic and non-neoplastic prostatic cell lines. Prostate 30: 219-231, 1997.

19. Kue PF and Daaka Y: Essential role for G proteins in prostate cancer cell growth and signaling. J Urol 164: 2162-2167, 2000.

20. Jarrard DF, Blitz BF, Smith RC, Patai BL and Rukstalis DB: Effect of epidermal growth factor on prostate cancer cell line PC3 growth and invasion. Prostate 24: 46-53, 1994.

21. Jones HE, Dutkowski CM, Barrow D, Harper ME, Wakeling AE and Nicholson RI: New EGF-R selective tyrosine kinase inhibitor reveals variable growth responses in prostate carcinoma cell lines PC-3 and DU-145. Int J Cancer 71: 1010-1018, 1997.

22. Motta M, Dondi D, Moretti RM, Montagnani Marelli M, Pimpinelli F, Maggi R and Limonta P: Role of growth factors, steroid and peptide hormones in the regulation of human prostatic tumor growth. J Steroid Biochem Mol Biol 56 (1-6 Spec No): 107-111, 1996.

23. Emons G, Muller V, Ortmann O and Schulz KD: Effects of LHRH-analogues on mitogenic signal transduction in cancer cells. J Steroid Biochem Mol Biol 65: 199-206, 1998.

24. Chen T, Cho RW, Stork PJ and Weber MJ: Elevation of cyclic adenosine 3',5'-monophosphate potentiates activation of mitogenactivated protein kinase by growth factors in LNCaP prostate cancer cells. Cancer Res 59: 213-218, 1999.

25. Peterziel H, Mink S, Schonert A, Becker M, Klocker H and Cato AC: Rapid signalling by androgen receptor in prostate cancer cells. Oncogene 18: 6322-6329, 1999.

26. Xiao D and Singh SV: Phenethyl isothiocyanate-induced apoptosis in p53-deficient PC-3 human prostate cancer cell line is mediated by extracellular signal-regulated kinases. Cancer Res 62: 3615-3619, 2002.
27. Bakin RE, Gioeli D, Sikes RA, Bissonette EA and Weber MJ: Constitutive activation of the Ras/mitogen-activated protein kinase signaling pathway promotes androgen hypersensitivity in LNCaP prostate cancer cells. Cancer Res 63: 1981-1989, 2003.

28. Gutierrez-Canas I, Juarranz MG, Collado B, Rodriguez-Henche N, Chiloeches A, Prieto JC and Carmena MJ: Vasoactive intestinal peptide induces neuroendocrine differentiation in the $\mathrm{LNCaP}$ prostate cancer cell line through PKA, ERK, and PI3K. Prostate 63: 44-55, 2005.

29. Yano S, Macleod RJ, Chattopadhyay N, Tfelt-Hansen J, Kifor O, Butters RR and Brown EM: Calcium-sensing receptor activation stimulates parathyroid hormone-related protein secretion in prostate cancer cells: role of epidermal growth factor receptor transactivation. Bone 35: 664-672, 2004.

30. Gioeli D, Mandell JW, Petroni GR, Frierson HF Jr and Weber MJ: Activation of mitogen-activated protein kinase associated with prostate cancer progression. Cancer Res 59: 279-284, 1999.

31. Bell WC, Myers RB, Hosein TO, Oelschlager DK and Grizzle WE: The response of extracellular signal-regulated kinase (ERK) to androgen-induced proliferation in the androgen-sensitive prostate cancer cell line, LNCaP. Biotech Histochem 78: 11-16, 2003.

32. Migliaccio A, Castoria G, Di Domenico M, de Falco A, Bilancio A, Lombardi M, Barone MV, Ametrano D, Zannini MS, Abbondanza $\mathrm{C}$ and Auricchio F: Steroid-induced androgen receptor-oestradiol receptor beta-Src complex triggers prostate cancer cell proliferation. EMBO J 19: 5406-5417, 2000.

33. Price DT, Della Rocca G, Guo C, Ballo MS, Schwinn DA and Luttrell LM: Activation of extracellular signal-regulated kinase in human prostate cancer. J Urol 162: 1537-1542, 1999.

34. Reiss N, Llevi LN, Shacham S, Harris D, Seger R and Naor Z: Mechanism of mitogen-activated protein kinase activation by gonadotropin-releasing hormone in the pituitary of alphaT3-1 cell line: differential roles of calcium and protein kinase $\mathrm{C}$. Endocrinology 138: 1673-1682, 1997.

35. Kraus S, Levy G, Hanoch T, Naor Z and Seger R: Gonadotropinreleasing hormone induces apoptosis of prostate cancer cells: role of c-Jun NH2-terminal kinase, protein kinase B, and extracellular signal-regulated kinase pathways. Cancer Res 64: 5736-5744, 2004.

36. Kimura A, Ohmichi M, Kurachi H, Ikegami H, Hayakawa J, Tasaka K, Kanda Y, Nishio Y, Jikihara H, Matsuura N and Murata Y: Role of mitogen-activated protein kinase/extracellular signal-regulated kinase cascade in gonadotropin-releasing hormone-induced growth inhibition of a human ovarian cancer cell line. Cancer Res 59: 5133-5142, 1999.

37. Yeh PY, Chuang SE, Yeh KH, Song YC, Chang LL and Cheng AL: Phosphorylation of p53 on Thr55 by ERK2 is necessary for doxorubicin-induced p53 activation and cell death. Oncogene 23: 3580-3588, 2004

38. Recio JA, Paez JG, Maskeri B, Loveland M, Velasco JA and Notario V: Both normal and transforming PCPH proteins have guanosine diphosphatase activity but only the oncoprotein cooperates with Ras in activating extracellular signal-regulated kinase ERK1. Cancer Res 60: 1720-1728, 2000.

39. Marchetti A, Cecchinelli B, D'Angelo M, D'Orazi G, Crescenzi M, Sacchi A and Soddu S: p53 can inhibit cell proliferation through caspase-mediated cleavage of ERK2/MAPK. Cell Death Differ 11: 596-607, 2004. 